\title{
Sex Discrimination in Employment Under Title IX
}

Section 901 of Title IX 1 of the Education Amendments of 1972 prohibits discrimination on the basis of sex in educational programs receiving federal financial aid. The basic prohibition of the statute is broadly worded. ${ }^{2}$ Although it clearly intends to prohibit sex discrimination by schools against students in admissions procedures and in decisions regarding awards of federal financial aid, a controversy has arisen over whether Congress intended this provision to apply as well to the employment practices ${ }^{3}$ of the schools receiving aid.

The Department of Health, Education, and Welfare ("HEW"),

1 Education Amendments of $1972 \S \S 901-907,20$ U.S.C. $\$ \S 1681-1686$ (1976).

2 "No person in the United States shall, on the basis of sex, be excluded from participation in, be denied the benefits of, or be subjected to discrimination under any education program or activity receiving Federal financial assistance." Id. \& 901, 20 U.S.C. § 1681 (1976). Exceptions to the section limit its applicability to institutions of vocational education, professional education, graduate higher education, and public undergraduate schools, and exclude the following from the section's operation: institutions in the process of changing from single-sex to coeducational admissions (for no more than seven years); educational institutions controlled by religious organizations whose tenets are inconsistent with the section; military academies; public undergraduate schools with a tradition of single-sex admissions; social fraternities and sororities; youth organizations traditionally open to a single sex; father-son and mother-daughter activities (so long as comparable activities are provided for children of the other sex); and financial assistance given as a result of successful competition in beauty pageants. Id.

s The scope of this comment is limited to employment practices affecting professional employees, as opposed to nonprofessional staff. Although the language of section 901 is not so limited, there is some evidence in the legislative history that Congress considered only professional employees to be covered. See, e.g., 118 Cong. REc. 5807 (1972) (remarks of Senator Bayh). The issue of who constitutes a professional employee, as well as whether only full-time employees or also part-time or adjunct faculty members are protected by the Act, is unresolved. Because all of the cases that have arisen so far have involved full-time faculty members, however, this comment does not attempt to resolve these issues. One possible solution would be to follow the comment's suggestion that the regulations be rewritten to refer only to specific programs receiving federal funds. At that time, the range of employees covered could also be defined.

1 As of May 4, 1980, all of the duties of HEW in the area of education were assumed by the newly created Department of Education, which reissued HEW's employment regulations, see note 6 infra, in identical form at 45 Fed. Reg. 30802 (1980) (to be codified in 34 C.F.R. $\S \S 106.51-.61)$. Recent suits have named the Department of Education as defendant 
lations to implement Title IX. ${ }^{6} \mathrm{HEW}$ determined that section 901 covered employment; consequently, the agency issued specific regulations governing employment practices. ${ }^{7}$ Since the regulations were issued, several schools have challenged HEW's interference with an area of their administration over which, they say, the Act and HEW have no control. Four courts of appeals have agreed with the schools, declaring the regulations invalid on the ground that Congress intended Title IX to protect only students and that, therefore, HEW exceeded its authority by issuing the employment regulations. $^{8}$

In July of 1980, the Second ${ }^{9}$ and Fifth ${ }^{10}$ Circuits disagreed. ${ }^{11}$ Both courts held that section 901 authorized HEW to issue regulations regarding employment, but even they differed over the scope of this power. This comment analyzes these cases, examines the legislative history of Title IX, and concludes that section 901 authorizes HEW to regulate employment practices, but that the agency must limit the effect of its regulations to specific programs that receive federal financial aid.

\section{History OF THE Act}

Both the courts that have declared HEW's regulations invalid and those that have ruled that the agency had authority to issue them have found the language of the statute inconclusive and have

in place of HEW. Because the functions and the regulations of the two departments are identical, this comment will refer to HEW as the agency involved for the sake of correspondence with the legislative history and the majority of the cases.

s 20 U.S.C. \& 1682 (1976).

- 45 C.F.R. $\$ \S 86.1-.61$ (1979).

Id. $\$ \S 86.51-.61$.

- Seattle Univ. v. HEW, 621 F.2d 992 (9th Cir.), cert. granted, 101 S. Ct. 563 (1981); Romeo Community Schools v. HEW, 600 F.2d 581 (6th Cir.), cert. denied, 444 U.S. 972 (1979); Junior College Dist. v. Califano, 597 F.2d 119 (8th Cir.), cert. denied, 444 U.S. 972 (1979); Islesboro School Comm. v. Califano, 593 F.2d 424 (1st Cir.), cert. denied, 444 U.S. 972 (1979). Only the Islesboro court undertook any detailed analysis of the problem; all of the other courts expressly followed it. See also Board of Educ. v. HEW, 19 Fair Empl. Prac. Cas. 457 (N.D. Ohio 1979); University of Toledo v. HEW, 464 F. Supp. 693 (N.D. Ohio 1979); Kuhn, Title IX: Employment and Athletics Are Outside HEW's Jurisdiction, 65 Geo. L.J. 49 (1976).

- North Haven Bd. of Educ. v. Hufstedler, 629 F.2d 773 (2d Cir. 1980), cert. granted, 49 U.S.L.W. 3617 (U.S. Feb. 24, 1981) (No. 80-986).

10 Dougherty County School Sys. v. Harris, 622 F.2d 735 (5th Cir.), petition for cert. filed, 49 U.S.L.W. 3495 (U.S. Dec. 22, 1980) (No. 80-1023).

11 See also Salomone, Title IX and Employment Discrimination: $A$ Wrong in Search of a Remedy, 9 J.L. \& Evuc. 433 (1980) (disagreeing with the first four courts of appeals decisions, but antedating the Second and Fifth Circuit opinions). 
resorted to congressional debates to support their holdings. In order to understand both the cases and the controversy, a brief recapitulation of the history of the Act is necessary.

Initially, the House and the Senate each passed its own version of the Education Amendments of $1971 .{ }^{12}$ The houses could not agree on the form the bill should take, so the Senate referred the dispute to its Committee on Labor and Public Welfare, which resolved the differences and recommended passage of the House version with some amendments. ${ }^{13}$ Both houses agreed to the compromise version in 1972, and the bill was enacted into law. The language of section 901 that became law corresponds closely to the versions originally introduced in both houses. ${ }^{14}$ Consequently, reference to all the debates gives valid insight into the congressional intent behind the section.

Two structural elements of Title IX are important to an understanding of this congressional intent. First, in writing Title IX, both houses relied on the structure and language of Title VI of the Civil Rights Act of $1964,{ }^{15}$ which banned discrimination on the bases of race, color, religion, and national origin in programs receiving federal aid. Section 901, in fact, is an almost verbatim repetition of section 601 of Title VI. ${ }^{16}$

Second, both the original House and Senate versions of Title IX included amendments to Title VII of the Civil Rights Act of $1964^{17}$ and to the equal pay provisions of the Fair Labor Standards

12 The Senate first passed its bill on August 6, 1971. S. 659, 92d Cong., 1st Sess., 117 ConG. REc. 30500 (1971). The House passed its bill on November 4, 1971, H.R. 7248, 92d Cong., 1st Sess., 117 Cong. Rec. 39353-54 (1971); the House then substituted its language for the Senate version and passed the bill in that form. 117 CoNG. REc. 39374 (1971).

13 S. Conr. Rep. No. 798, 92d Cong., 2d Sess., reprinted in [1972] U.S. Cone Cong. \& AD. NEws 2608. Most of the amendments concerned provisions of the Education Amendments of 1972 other than Title IX. Id. at 221, reprinted in [1972] U.S. CoDE CoNG. \& AD. News 2608, 2671. The Title IX disputes between the House and Senate had to do primarily with the exceptions to section 901. Id.

14 Compare H.R. 7248, 92d Cong., 1st Sess., 117 Cong. REc. 39098 (1971) (here numbered Title X) with S. 659, 92d Cong., 1st Sess., 117 Cong. REc. 30399 (1971) (first Senate version, here numbered Title VI) and S. 659, 92d Cong., 2d Sess., 118 Cong. Rec. 5803 (1972) (second Senate version, here numbered Title X). See also S. Conf. REP. No. 798, 92d Cong., 2d Sess. 221, reprinted in [1972] U.S. Code Cong. \& AD. NEws 2608, 2671.

${ }_{15}$ Civil Rights Act of $1964 \S \S 601-605,42$ U.S.C. $\$ \S 2000 \mathrm{~d}-2000 \mathrm{~d}-4$ (1976).

18 Id. $\S 601,42$ U.S.C. $\$ 2000$ d (1976). That provision states: "No person in the United States shall, on the ground of race, color, or national origin, be excluded from participation in, be denied the benefits of, or be subjected to discrimination under any program or activity receiving Federal financial assistance." Section 901 simply substitutes "on the basis of sex" for the criteria of race, color, and national origin listed in section 601. See note 2 supra.

17 Civil Rights Act of $1964 \S \S 701-718,42$ U.S.C. $\S \S 2000$ e-2000e-17 (1976 \& Supp. II 
Act 18 ("Equal Pay Act"), adding a prohibition against discrimination on the basis of sex to those statutes. The drafters included these provisions in section 906 of Title IX, but before the Education Amendments were passed, the alteration to Title VII was effected by the Equal Employment Opportunity Act of 1972.18 The amendment to the Equal Pay Act was enacted as section $906(\mathrm{~b})(1) .^{20}$

\section{Congressional Intent}

With regard to the question of Congress's intent, the legislative history of Title IX is ambiguous. Both groups of courts-those deciding that Congress did not intend section 901 to cover employment, and those deciding that it did-relied on the language of the statute and some of the same portions of the legislative record for their contrary conclusions. But an analysis of the legislative history reveals that the weight of the evidence indicates congressional intent to regulate employment through section 901 .

\section{A. Statutory Language}

The First Circuit in Islesboro School Committee v. Califano ${ }^{21}$ held that the language of section 901 , "on its face, is aimed at the beneficiaries of the federal monies." ${ }^{22}$ By beneficiaries, the court meant students enrolled in schools receiving federal aid or teachers receiving research grants ${ }^{23}$ from the government. ${ }^{24}$ From this, the court inferred a congressional intent to exclude employees from the Act's coverage.

1978).

1829 U.S.C. $\$ \S 201-219$ (1976).

10 Pub. L. No. 92-261, $\S \S 2-3,86$ Stat. 103 (amending 42 U.S.C. $\S \S 2000 \mathrm{e}(a), 2000 \mathrm{e}-1$ (1976)).

${ }^{30}$ Education Amendments of 1972, Pub. L. No. 92-318, $\S 906(b)(1), 86$ Stat. 375 (codified at 29 U.S.C. $\$ 213$ (a) (1976)).

21593 F.2d 424 (lst Cir.), cert. denied, 444 U.S. 972 (1979).

${ }_{22}$ Id. at 426. Accord, Romeo Community Schools v. HEW, 600 F.2d 581, 584 (6th Cir.), cert. denied, 444 U.S. 972 (1979); Junior College Dist. v. Califano, 597 F.2d 119, 121 (8th Cir.), cert. denied, 444 U.S. 972 (1979). But see North Haven Bd. of Educ. v. Hufstedler, 629 F.2d 773, 777-78 (2d Cir. 1980), cert. granted, 49 U.S.L.W. 3617 (U.S. Feb. 24, 1981) (No. 80-986); Dougherty County School Sys. v. Harris, 622 F.2d 735, 737-38 (5th Cir.), petition for cert. filed, 49 U.S.L.W. 3495 (U.S. Dec. 22, 1980) (No. 80-1023). See also Board of Educ. v. HEW, 19 Fair Empl. Prac. Cas. 457 (N.D. Ohio 1979); University of Toledo v. HEW, 464 F. Supp. 693 (N.D. Ohio 1979).

23 That is, teachers qua students, not qua employees.

24 593 F.2d at 426 . 
Neither in its basic prohibition nor in its exceptions, however, does the statute expressly exclude employees from its protection. One can make a strong contrary argument that they are implicitly embraced within the broad language of section 901 . In addition to language that clearly refers to students, ${ }^{25}$ section 901 also requires that no person shall "be subjected to discrimination under" any federally funded educational program. ${ }^{26}$ It is plausible that this language, which is much broader in scope than the language referring to students alone, was calculated to cover those employees whose jobs are funded by federal dollars. Moreover, Congress used the all-inclusive words "no person" to designate the protected class. If, as the Islesboro court suggested, a more circumscribed class was intended, Congress easily could have substituted "student" or Islesboro's own word, "beneficiary," to restrict the scope of the statute's protection.

In order to support their contention that the section refers only to beneficiaries, some courts have pointed out that none of the exceptions listed in section $901^{27}$ refers to employees or employment practices. ${ }^{28}$ The argument is that because the exceptions apply only to aspects of education that affect students, they reflect the limits Congress intended to place on the scope of the basic prohibition. ${ }^{28}$ That the exceptions do not mention employment, however, shows only that employment is not specifically excluded. The exceptions cannot be construed as limiting the coverage of the Act to students. ${ }^{30}$ If anything, in light of the broad scope of the basic

${ }^{25}$ "No person . . . shall . . . be excluded from participation in, [or] be denied the benefits of . . . Education Amendments of 1972 \& 901,20 U.S.C. $\$ 1681$ (1976); see note 2 supra.

${ }^{26}$ Education Amendments of $1972 \S 901,20$ U.S.C. $\S 1681$ (1976); see note 2 supra.

${ }^{27}$ See note 2 supra.

28 Romeo Community Schools v. HEW, 600 F.2d 581, 583-84 (6th Cir.), cert. denied, 444 U.S. 972 (1979); Islesboro School Comm. v. Califano, 593 F.2d 424, 426 (1st Cir.), cert. denied, 444 U.S. 972 (1979). The legislative history is to the contrary on this point. See 118 CoNG. Rec. 5812 (1972) (remarks of Sen. Bayh); text and notes at notes 41-42 infra.

${ }^{28}$ The Islesboro court, for example, notes that the exceptions "all deal with student admissions or activities of a student nature" and that section 901 therefore cannot be construed to apply to "employees qua employees." 593 F.2d at 426.

so Indeed, two of the exceptions-those sections exempting religious-controlled institutions and military organizations-never mention students or admissions, but recognize that these types of schools have valid reasons for generally excluding one sex or the other. It is quite easy to understand that in these two situations, an exemption from section 901 should be created for both admissions and employment. In contrast, in the situations described in exemptions such as that for public undergraduate schools with a history of single-sex admissions, there is no reasonable explanation for excluding faculty members of one sex; hence, such exemptions specifically apply only to admissions. In fact, Senator Bayh suggested that 
prohibition, the absence of a specific exclusion supports the argument that the Act covers employment.

It is possible, therefore, to read the language of section 901 as embracing employees. Because it nowhere specifically excludes them, the most that can be deduced from the face of section 901 regarding employment is that it is inconclusive. One must look, therefore, to the legislative history for additional evidence of Congress's intent.

\section{B. Legislative History}

The legislative history reflects in three ways an intent to include employment within the embrace of section 901. First, the debates contain numerous remarks pertaining to employment. ${ }^{31} \mathrm{Al}-$ though some of these remarks can be attributed to the early inclusion in Title IX of amendments to Title VII and the Equal Pay Act, ${ }^{32}$ others give evidence of a more general aim to have section 901 cover employment. Second, the Committee on Labor and Public Welfare, in creating a compromise version of Title IX, ${ }^{33}$ removed a provision from the House bill that expressly exempted employment from the Act's coverage. The concurrence by both houses in the deletion of this provision supports the inference that Congress intended employment to be covered. Finally, after Title IX was enacted, HEW's regulations construing section 901 as embracing employment were approved by Congress, after remarks made at the hearings reflected an understanding that the regulations implemented congressional intent. Subsequent attempts to amend section 901 to exclude employment have failed.

1. Debates. One argument for excluding employment from the scope of Title IX relies on the inclusion in the original bill of amendments to Title VII and the Equal Pay Act. ${ }^{34}$ That argument admits the existence in the legislative history of references seemingly indicating that Title IX covers employment. It explains them

the exceptions do just that. See 118 Cong. REc. 5812-13 (remarks of Sen. Bayh); text and notes at notes $41-42$ infra.

s1 The debates are cited throughout this comment because they are the only evidence of legislative intent. The reports, on the rare occasion when they mention employment, are inconclusive because of the existence of the proposed amendments to Title VII and the Equal Pay Act. See, e.g., H.R. RkP. No. 554, 92d Cong., 1st Sess. 51, 52, 251, reprinted in [1972] U.S. Code Cong. \& AD. News 2462, 2511-12, 2590.

${ }^{32}$ See text and notes at notes 17-20 supra.

ss See text and notes at notes 12-16 supra.

st See text and notes at notes 17-20 supra. 
all away, however, as referring only to the proposed amendments to Title VII and the Equal Pay Act. ${ }^{35}$

Several passages from the debates belie this conclusion. For example, when Senator Bayh reintroduced the bill in $1972,{ }^{36}$ he entered into the record a prepared statement explaining the scope of the proposed statute..$^{37}$ In this summary he divided the bill into its basic areas of coverage, two of which were entitled "Prohibition of Sex Discrimination in Federally Funded Education Programs" -the Title VI counterpart that now includes section 901-and "Prohibition of Education-Related Employment Discrimination"-the revisions to Title VII and the Equal Pay Act.

Under the first of these headings, Senator Bayh spoke not only of admissions and scholarships, but also of employment in federally funded schools. He noted the close relation between this portion of his bill and Title VI, and he mentioned the exceptions to the basic prohibition that this portion allows. Both of these statements indicate that he was speaking of what is now section 901. Nowhere under this heading did Senator Bayh mention Title VII and the Equal Pay Act, ${ }^{38}$ yet he declared, "[t]his portion of the amendment covers discrimination in all areas where abuse has

ss See Romeo Community Schools v. HEW, 600 F.2d 581, 582 (6th Cir.), cert. denied, 444 U.S. 972 (1979); Islesboro School Comm. v. Califano, 593 F.2d 424, 427-28 (1st Cir.), cert. denied, 444 U.S. 972 (1979). Islesboro notes that according to Senator Bayh, Title IX applied to three areas of discrimination: admissions and services, both of which affect students, and hiring, which affects employees. Id. at 427. Because the portions of the bill amending Title VII and the Equal Pay Act remedied employment discrimination, the Islesboro court assumed that they were the only sections of the bill that so applied and that all references to employment pertained to those provisions. Id. at 428; accord, Romeo Community Schools v. HEW, 600 F.2d 581, 585 (6th Cir.), cert. denied, 444 U.S. 972 (1979). All that the court cites as support, however, are sections of the legislative history where Senator Bayh specifically referred to the amendments to Title VII and the Equal Pay Act. 593 F.2d at 427-28. These remarks prove only that those portions of the bill affected employment; they give no insight about what was intended by the portion that is now section 901 .

se When Senator Bayh first introduced the forerunner of section 901 in 1971, it did not come to a vote because it was ruled not germane to the pending bill that it sought to amend. 117 Cong. Rec. 30415 (1971).

37118 Cong. Rec. 5806-08 (1972).

38 One inconsistency must be noted. Senator Bayh prefaced his remarks to this section of his summary by referring to sections "1001-1005." Id. at 5807. Section 1005 contained the proposed revision to Title VII. See id. Three reasons indicate, however, that the inclusion of section 1005 in his opening remarks was a mistake: first, Senator Bayh did not also list at that time the sections revising the Equal Pay Act; second, in his explanation of the coverage of the mentioned sections he never discussed the Title VII amendments; and third, he discussed the Title VII amendments at length under the other heading. See North Haven Bd. of Educ. v. Hufstedler, 629 F.2d 773, 781 n.11 (2d Cir. 1980), cert. granted, 49 U.S.L.W. 3617 (U.S. Feb. 24, 1981) (No. 80-986). 
been mentioned-employment practices for faculty and administrators, scholarship aid, admissions, access to programs within the institution such as vocational education classes, and so forth." ${ }^{3 \theta}$ All of Senator Bayh's references to Title VII and the Equal Pay Act come under the heading especially devoted to them. There is no mistaking that this prepared statement by the sponsor of the bill indicates an intent to establish in section 901 a broad-based prohibition against employment discrimination. ${ }^{40}$

This intent is further demonstrated in a colloquy between Senator Bayh and Senator Pell regarding the scope of section 901 and its exceptions. Senator Bayh explained that the exceptions to the basic prohibition applied only to admissions procedures in certain types of institutions. "In the case of employment," he emphasized, "we permit no exceptions." 1 In fact, this declaration was something of an overstatement. Senator Bayh went on to note that religious and military organizations were exempted from the operation of section 901 not only for admissions but for employment of teachers as well. ${ }^{42}$ These explanations of the intended scope of section 901 demonstrate that its prohibition against discrimination on the basis of sex was thought to extend to employment. ${ }^{43}$

Debates in the House similarly indicate an intent to include employment within the reach of section 901 . For example, the remarks of Representative Erlenborn when he proposed to amend the House bill reflect an assumption that the bill forbade sex discrimination in employment. Erlenborn stated that the only aspect of Title IX his amendment changed was the exemption of under-

39 118 Cong. Rec. 5807 (1972) (emphasis added).

10 The Islesboro court cited another summary of the bill that Senator Bayh read into the record, see 118 CoNG. REc. 5808 (1972), as further proof of its view that Title IX could be broken down into portions affecting only students and portions affecting only employees. The summary to which it referred divides the bill into sections, three of which are entitled "Basic Prohibition," "Employment Discrimination," and "Equal Pay for Professional Women." The "Basic Prohibition" section contains a truncated version of the language of section 901 and its exceptions, the "Employment Discrimination" section contains a summary of the proposed amendments to Title VII, and the "Equal Pay" section summarizes the amendments to the Equal Pay Act. The court concluded from this summary that only the latter two sections of the bill apply to employment. 593 F.2d at 428. This conclusion is incorrect because the summary the court cited is only an abbreviated version of the actual language of the bill rather than commentary on the bill; therefore, it sheds no more light on the problem than does the statute itself.

4118 CoNg. Rec. 5812 (1972).

42 Id. at 5813.

4 Accord, North Haven Bd. of Educ. v. Hufstedler, 629 F.2d 773, 782 (2d Cir. 1980), cert. granted, 49 U.S.L.W. 3617 (U.S. Feb. 24, 1981) (No. 80-986). 
graduate admissions. "My amendment would allow the effects of nondiscrimination in this title to apply to faculty, to employees, and to admissions practices in the graduate schools so that the entry to the professions would be protected . . . ."44

This position was echoed by Representative Smith, who said that the Erlenborn amendment would "leave the prohibition against sex discrimination to apply to graduate education and faculty employment and salaries." "Is In addition, Representative Quie reflected the same disposition when he introduced his amendment providing that the bill should require no quotas. ${ }^{46}$ Although there was considerable debate regarding these and other amendments, no one ever questioned the initial assumption that the basic prohibition of the bill applied to employment. These remarks are all the more conclusive when one considers that they were made while the bill still contained a clause stating expressly that the statute would not cover employment. ${ }^{47}$

A letter from Senator Bayh to Senator Pell, responding to an inquiry from Professor Julian Levi of the University of Chicago about the bill's effect on university hiring practices, offers additional evidence of congressional intent. Professor Levi had written after the proposed amendment to Title VII was removed from Title IX because of its inclusion in the Equal Employment Opportunity Act of 1972, but before Title IX became law. Senator Bayh's response indicated that one of the primary purposes of Title IX-even in the absence of the Title VII provision-was to prohibit sex discrimination against professional employees in educational institutions. ${ }^{48}$

2. Exemption of Employment in the House Version. The second aspect of the legislative history that reflects an intent to include employment within the scope of Title IX is the removal from the House version of the bill of a provision expressly exempting employment. ${ }^{49}$ This section did not appear in the Senate bills,

14 117 Cong. REc. 39260 (1971).

16 Id. at 39255 .

18 Id. at 39262.

17 See text and notes at notes 49-56 infra.

18118 Cong. REc. 18437 (1972).

19 Section 904 of the original House version of Title IX stated: "Nothing contained in this title shall be construed to authorize action under this title by any department or agency with respect to any employment practice of any employer, employment agency, or fabor organization except where a primary objective of the Federal financial assistance is to provide employment." H.R. 7258, 92d Cong., 1st Sess., 117 Cong. Rec. 39365 (1971). The section paralleled and was modeled after section 604 of Title VI, Civil Rights Act of 1964 
nor was it a part of the version of Title IX that became law. There were no debates in the House regarding the provision, nor were there in the Senate when it disapproved the House version. The conference report implies that the Committee on Labor and Public Welfare recommended removal of the provision-without comment regarding its reasons ${ }^{31}$ - and that the House made no effort to retain the section. The report simply states that with regard to that provision, "[ $t]$ he House recedes." 32

Courts have argued that, given the early existence in Title IX of the amendments to Title VII and the Equal Pay Act, the removal of this clause was only for the sake of consistency with those provisions. This reasoning maintains that the initial inclusion of the clause demonstrates an aim to exempt employment from the scope of section 901, in exact correspondence with Title VI after which the bill was modeled. ${ }^{53}$ Such an argument is easily refuted, however. There is no evidence in the legislative history that a desire to avoid inconsistency was the motive for removing the clause. Moreover, the debates in which the House legislators expressed their belief that the bill covered employment ${ }^{\text {st }}$ reveal no perception of inconsistency. In fact, these debates point more strongly to a complete lack of awareness that the employment exemption section existed.

A more plausible explanation for the section's original inclusion is that it was mistakenly inserted by the original drafters who were tracking the language of the model bill, Title VI. ${ }^{\text {ss }}$ The committee, the first to notice its presence, probably recommended its deletion because it was contrary to the purpose of section 901 . This explanation comports with the lack of discussion about the provi-

$\S 604,42$ U.S.C. $\$ 2000$ d-3 (1976). In fact, it was because section 601 , the counterpart to the broad prohibition of section 901 , was interpreted by some as embracing employment, that section 604 was enacted. See North Haven Bd. of Educ. v. Hufstedler, 629 F.2d 773, 778 (2d Cir. 1980), cert. granted, 49 U.S.L.W. 3617 (U.S. Feb. 24, 1981) (No. 80-986); Kuhn, supra note 8 , at $53-54$.

so See S. 659, 92d Cong., 1st Sess., 117 Cong. Rzc. 30500 (1971); S. 659, 92d Cong., 2d Sess., 118 CoNG. Rec. 5803 (1972).

s1 S. Cong. Rep. No. 798, 92d Cong., 2d Sess. 221, reprinted in [1972] U.S. Code Cong. \& AD. NEws 2608, 2671-72.

${ }^{62}$ Id., reprinted in [1972] U.S. CoDs CoNg. \& AD. News 2608, 2672.

${ }^{63}$ Romeo Community Schools v. HEW, 600 F.2d 581, 584 (6th Cir.), cert. denied, 444 U.S. 972 (1979); Islesboro School Comm. v. Califano, 593 F.2d 424, 428 (1st Cir.), cert. denied, 444 U.S. 972 (1979).

st See text and notes at notes 44-47 supra.

ss See North Haven Bd. of Educ. v. Hufstedler, 629 F.2d 773, 778, 783 (2d Cir. 1980), cert. granted, 49 U.S.L.W. 3617 (U.S. Feb. 24, 1981) (No. 80-986). 
sion in either house and the willingness of the House to recede on the point without argument.

Furthermore, the houses voted on removal of the provision after the enactment of the Equal Employment Opportunity Act provoked the deletion from Title IX of the amendments to Title VII. Although the amendment to the Equal Pay Act remained, it was a very small part of Title IX. If the legislators had wanted to make clear that only the equal pay provision, and not section 901, applied to employment, they could have expressly limited the effect of the employment exemption section to Title IX's broad prohibition. ${ }^{\mathrm{s}}$

There is additional evidence that bolsters this view. In a summary of the final version of the bill that Senator Bayh published in the Congressional Record after the enactment of Title IX, a footnote explained the difference between Title VI and Title IX. This note states explicitly that Title IX does not parallel the Title VI exemption for employment.

3. Postenactment Evidence of Congress's Intent. After Title IX was enacted, further indications of congressional intent appeared. First, HEW promulgated regulations that included strictures on employment practices. Although Congress had an opportunity to disapprove of the regulations, it declined to do so; hence, the regulations became valid. ${ }^{88}$ Second, at hearings on the regulations, both Representative Mink and Senator Bayh stated specifi-

se See id. at 783.

s7 The note states:

Apart from admission coverage . . . , the Higher Education Act differs from Title VI in that the sex discrimination prohibition is limited to federally assisted education programs and activities, whereas the race, color and national origin discrimination prohibitions are applicable to all federally assisted programs. Title VI also specifically excludes employment from coverage (except where the primary objective of the federal aid is to provide employment). There is no similar exemption for employment in the sex discrimination provisions relating to federally assisted education programs.

118 CoNG. Rzc. 24684 n.1 (1972) (emphasis in original).

ss By congressional decree, this inaction is not entitled to any weight, one way or the other, in a judicial proceeding. 20 U.S.C. $\$ 1232$ (d)(1) (1976); see Salomone, supra note 11, at 443. As the North Haven court noted, however, this statute was enacted after the regulations issued under Title IX became valid. Moreover, the subsequent refusal of Congress to adopt amendments excluding employment from the scope of section 901 adds further support for the conclusion that coverage was intended. 629 F.2d at 784; see NLRB v. Bell Aerospace Co., 416 U.S. 267, 275 (1974).

It should also be noted here that, according to a frequently employed canon of statutory interpretation, in the absence of compelling evidence to the contrary an agency's understanding of the scope of its statutorily delegated powers generally is given considerable weight. See, e.g., id. at 274-75; Griggs v. Duke Power Co., 401 U.S. 424, 433-34 (1971). 
cally that the regulations implemented the intent of Congress to prohibit discrimination in employment. ${ }^{59}$ Although these retrospective statements cannot be conclusive, ${ }^{60}$ they are persuasive when read in light of the other legislative history. Third, some legislators subsequently attempted to amend Title IX by expressly removing employment from the reach of section $901 .^{\circ 1}$ All such attempts failed. Finally, Congress has amended Title IX to overrule HEW's interpretations of the statute on two occasions. ${ }^{62}$ Its failure to take those opportunities to deal with the employment issue as well lends further support to the inference that it never desired to do so. ${ }^{63}$

\section{Policy Considerations}

There are two policy arguments for reading section 901 to exclude employment. The first is that allowing HEW to terminate funds because of employment discrimination would result in injury to the students enrolled in those programs. The argument maintains that it would not be fair to force students to suffer for the sake of eradicating discrimination against teachers; therefore, Congress could not have intended section 901 to apply to employment. ${ }^{\text {B4 }}$

This argument is perhaps emotionally appealing, but it is superficial. In section 902 , Congress gave HEW the authority to terminate funds to an entire program to the temporary detriment of all students, even in the case where only a small minority of students have been victims of discrimination. ${ }^{65}$ That innocent and uninvolved students can be made to suffer temporarily by HEW's

so Sex Discrimination Regulations: Hearings Before the Subcomm. on Postsecondary Education of the House Comm. on Education and Labor, 94th Cong., 1st Sess. 164, 173 (1975).

so See North Haven Bd. of Educ. v. Hufstedler, 629 F.2d 773, 784 (2d Cir. 1980), cert. granted, 49 U.S.L.W. 3617 (U.S. Feb. 24, 1981) (No. 80-986); Salomone, supra note 11, at 442-43.

61 S. 2146, 94th Cong., 1st Sess. (1975); S. 2657, 94th Cong., 2d Sess. (1976).

-2 20 U.S.C. $\$ \S 1681$ (a)(8) (1976) (exempting father-son and mother-daughter activities at educational institutions); $i d . \S 1681(a)(9)$ (exempting awards granted to winners of beauty pageants). See North Haven Bd. of Educ. v. Hufstedler, 629 F.2d 773, 784 (2d Cir. 1980), cert. granted, 49 U.S.L.W. 3617 (U.S. Feb. 24, 1981) (No. 80-986).

63 See North Haven Bd. of Educ. v. Hufstedler, 629 F.2d 773, 784 (2d Cir. 1980), cert. granted, 49 U.S.L.W. 3617 (U.S. Feb. 24, 1981) (No. 80-986).

of Romeo Community Schools v. HEW, 600 F.2d 581, 584 (6th Cir.), cert. denied, 444 U.S. 972 (1979).

os Education Amendments of 1972 § 902, 20 U.S.C. $\$ 1682$ (1976). 
termination of funds is a necessary evil of the statute; therein lies its potency.

Congress could not have been unaware of these ramifications of Title IX; ${ }^{66}$ Title VI had been in effect for several years before Title IX was considered, and Congress consciously duplicated the force and remedy of that statute. ${ }^{67}$ In so doing, it expressed the hope that HEW would use its power wisely and sparingly, but it recognized as necessary the leverage that the power to terminate funds would give HEW against recalcitrant schools. ${ }^{68}$ The prospect of fund termination not only for discrimination against students, but also for discrimination against teachers, makes Title IX all the more effective against sex discrimination. ${ }^{6 \theta}$

The second policy argument is that Title IX was never intended to cover employment because it would then have overlapped with the jurisdiction of Title VII and the Equal Pay Act. ${ }^{70}$ In effect, however, there is only a partial overlap. While a private right of action has been found to exist under all three acts, ${ }^{71}$ there are differences in the remedies available under each. ${ }^{72}$ Employees may sue individually under both Title VII ${ }^{\text {rs }}$ and the Equal Pay Act $^{74}$ for such remedies as reinstatement and back pay. It is only under Title IX that Congress has granted to HEW the potential to cut off a school's federal funds for violating the statute's prohibi-

${ }^{68}$ Indeed, the legislative history demonstrates that Congress was aware of the impact that the termination-of-funds remedy would have on students. See text and notes at notes 67-69 infra.

67 E.g., 117 Cong. Rec. 30408 (1971) (remarks of Sen. Bayh); 118 Cong. REc. 5807 (1972) (remarks of Sen. Bayh); see Salomone, supra note 11, at 434.

eB 117 CoNG. REc. 30408 (1971) (remarks of Sen. Bayh); see North Haven Bd. of Educ. v. Hufstedler, 629 F.2d 773, 785 (2d Cir. 1980), cert. granted, 49 U.S.L.W. 3617 (U.S. Feb. 24,1981 ) (No. 80-986).

69 See North Haven Bd. of Educ. v. Hufstedler, 629 F.2d 773, 785 (2d Cir. 1980), cert. granted, 49 U.S.L.W. 3617 (U.S. Feb. 24, 1981) (No. 80-986); Salomone, supra note 11, at 447.

70 See Romeo Community Schools v. HEW, 600 F.2d 581, 584 (6th Cir.), cert. denied, 444 U.S. 972 (1979). But see North Haven Bd. of Educ. v. Hufstedler, 629 F.2d 773, 784-85 (2d Cir. 1980), cert. granted, 49 U.S.L.W. 3617 (U.S. Feb. 24, 1981) (No. 80-986); Salomone, supra note 11; Comment, The Regulation of Title IX: Sex Discrimination in Student Affairs, 13 Hous. L. REv. 734, 737-39 (1976).

is Title VII and the Equal Pay Act expressly grant private rights of action. See notes 73-74 infra. An implied private right of action under Title IX was recognized only recently by the Supreme Court in Cannon v. University of Chicago, 441 U.S. 677, 694-703 (1979).

72 See Salomone, supra note 11, at 439.

73 Civil Rights Act of 1964 \& 706(g), 42 U.S.C. $\S 2000 \mathrm{e}-5(\mathrm{~g})(1976)$.

7429 U.S.C. § 216 (b) (1976). 
tion against sex discrimination. ${ }^{75}$ Both the individual remedies and the system-wide one are important to the overall scheme of eradicating sex discrimination. ${ }^{76}$

Moreover, even if the effects of the statutes overlap, this is not a reason for failing to implement the congressional intent expressed in Title IX. Overlapping jurisdiction in the area of employment discrimination is widely recognized. ${ }^{77}$ In addition, Title IX, like other antidiscrimination laws, is a remedial statute and therefore should be construed liberally in order to implement its corrective purposes.

\section{A NECESSARy Limitation ON THE ScOPE OF HEW'S REgULATIONS}

Although the preceding analysis compels the conclusion that Congress intended section 901 to cover employment, it does not necessarily follow that HEW's broad regulations are valid. HEW has taken the approach that any discrimination within a school system receiving federal funds gives it the power to terminate funds to the whole system, regardless of whether the program receiving the funds itself discriminates. ${ }^{78} \mathrm{HEW}$ 's regulations accordingly are written to monitor all employment practices of schools receiving any federal aid, instead of being limited to the specific programs within the school that actually receive the funds. ${ }^{79}$ Such an interpretation of the agency's power is contrary to the language of section 902, to the intention of Congress, and to rational policy considerations.

The language of section 902 of the statute unambiguously states that HEW's rulemaking authority is limited to the particular program or activity receiving federal aid. ${ }^{80}$ Just as the prohibi-

78 Education Amendments of $1972 \S 902,20$ U.S.C. $\$ 1682$ (1976).

76 See North Haven Bd. of Educ. v. Hufstedler, 629 F.2d 773, 784-85 (2d Cir. 1980), cert. granted, 49 U.S.L.W. 3617 (U.S. Feb. 24, 1981) (No. 80-986); Salomone, supra note 11, at 439; Comment, Title IX of the 1972 Education Amendments: Preventing Sex Discrimination in Public Schools, 53 TEx. L. REv. 103, 120-21 (1974).

77 North Haven Bd. of Educ. v. Hufstedler, 629 F.2d 773, 784-85 (2d Cir. 1980), cert. granted, 49 U.S.L.W. 3617 (U.S. Feb. 24, 1981) (No. 80-986); see Johnson v. Railway Express Agency, Inc., 421 U.S. 454, 459 (1975); Alexander v. Gardner-Denver Co., 415 U.S. 36, 47-49 (1974).

${ }^{78}$ See Dougherty County School Sys. v. Harris, 622 F.2d 735, 737 (5th Cir.), petition for cert. filed, 49 U.S.L.W. 3495 (U.S. Dec. 22, 1980) (No. 80-1023); Islesboro School Comm. v. Califano, 593 F.2d 424, 430 (1st Cir.), cert. denied, 444 U.S. 972 (1979).

70 See 45 C.F.R. $\$ \$ 86.51-.61$ (1979).

so Section 902 states: 
tion of section 901 is keyed to "any education program or activity receiving Federal financial assistance," of the enabling statute must the regulations govern only the program receiving federal aid. ${ }^{82}$

The Second Circuit, in North Haven Board of Education $v$. Hufstedler, ${ }^{83}$ distinguished in dicta the question of fund termination from the issue of the agency's regulations. It maintained that although section 902 limited HEW's ability to terminate funds to the specific program in which discrimination occurred, nothing so restricted its rulemaking authority. ${ }^{84}$ This distinction makes no sense, however. There is no reason why HEW's rulemaking authority should be any broader than its enforcement power. The North Haven court's reading of the statute would enable HEW to regulate a school's entire employment system, even though it could only cut off funds to the programs that received federal aid. Such a result would be erroneous for several reasons.

First, the power to regulate so broadly could enable HEW to harass schools and threaten termination of their funds without having to link the discrimination with the federal funding until much later in the enforcement process. ${ }^{85}$ Given the drastic implications of a cutoff of funds, HEW's power should be limited to only those programs that both receive the aid and unlawfully discrimi-

Each Federal department and agency which is empowered to extend Federal financial assistance to any education program or activity, . . . is authorized and directed to effectuate the provisions of section 901 with respect to such program or activity by issuing rules, regulations, or orders of general applicability which shall be consistent with achievement of the objectives of the statute authorizing the financial assistance in connection with which the action is taken.

20 U.S.C. § 1682 (1976) (emphasis added).

This comment does not address the much-debated question of what constitutes a program or activity for the sake of enforcement of Titles VI and IX. For discussion of this issue, see Comment, HEW's Regulations Under Title IX of the Education Amendments of 1972: Ultra Vires Challenges, 1976 B.Y.U.L. REv. 133; Note, Administrative Cutoff of Federal Funding Under Title VI: A Proposed Interpretation of "Program," 52 IND. L.J. 651 (1977); Note, Title VI, Title IX and the Private University: Defining "Recipient" and "Program or Part Thereof," 78 Mick. L. REv. 608 (1980).

${ }^{81} 20$ U.S.C. $\S 1681$ (a) (1976).

${ }^{82}$ See Dougherty County School Sys. v. Harris, 622 F.2d 735, 737 (5th Cir.), petition for cert. filed, 49 U.S.L.W. 3495 (U.S. Dec. 22, 1980) (No. 80-1023); Romeo Community Schools v. HEW, 600 F.2d 581, 584 (6th Cir.), cert. denied, 444 U.S. 972 (1979).

${ }^{83} 629$ F.2d 773 (2d Cir. 1980), cert. granted, 49 U.S.L.W. 3617 (U.S. Feb. 24, 1981) (No. 80-986).

84 Id. at 785-86; see Salomone, supra note 11, at 439 n.28. But see Comment, supra note 80.

${ }^{85}$ See Islesboro School Comm. v. Califano, 593 F.2d 424, 430 (1st Cir.), cert. denied, 444 U.S. 972 (1979). 
nate. ${ }^{86}$ Second, such expansive power to regulate cannot legitimately be granted to HEW. By the language of section 902, HEW has not even the power to regulate a program funded by another federal agency ${ }^{87}$ much less a program not funded at all by federal money. Therefore, the agency logically can have no semblance of control over an aspect of a school's operation to which it has not allocated federal funds. Third, HEW's broad regulations would allow the inference in every case that discrimination in any area of a school infects the entire system so that all federal funds to the school, whether directly linked with the discrimination or not, should be terminated. Such an inference cannot validly be drawn except according to the facts of an individual case. Finally, limiting HEW's enforcement powers to the specific program receiving federal funds corresponds with the agency enforcement powers granted under Title $\mathrm{VI}^{88}$ and carries out Congress's intent that Title IX should be enforced in the same way as Title VI. ${ }^{89}$

\section{Conclusion}

The legislative history and the language of section 901 demonstrate that Congress granted HEW the power to regulate educational employment practices under that provision. HEW has exceeded its authority, however, by failing to limit the effects of its regulations to specific programs receiving federal funds. Although Congress's purpose in establishing Title IX and in vesting strong enforcement powers in HEW was to eradicate swiftly the effects of sex discrimination, the agency must amend its regulations to stay within the scope of its statutory mandate.

Lynda Guild Simpson

*4 See Othen v. Ann Arbor School Bd., 49 U.S.L.W. 2569 (E.D. Mich. Feb. 23, 1981). But see Salomone, supra note 11, at 446 (so limiting HEW's power would unduly restrict Title IX's coverage to a narrow set of employment situations).

I See note 80 supra.

*s Compare 20 U.S.C. § 1682 (1976) with 42 U.S.C. § 2000d-1 (1976) (enforcement); compare 20 U.S.C. $\$ 1683$ (1976) with 42 U.S.C. $\$ 2000 \mathrm{~d}-2$ (1976) (judicial review).

so 117 CoNG. REc. 30408 (1971) (remarks of Sen. Bayh); see Salomone, supra note 11, at 441. 